JEKPEND Jurnal Ekonomi dan Pendidikan

Volume 2 Nomor 1 Januari 2019. Hal. 44-50

p-ISSN: 2614-2139; e-ISSN: 2614-1973,

Homepage:http://ojs.unm.ac.id/JEKPEND

\title{
PENGARUH TINGKAT PARTISIPASI PEREMPUAN DALAM BERWIRAUSAHA TERHADAP TINGKAT SOSIAL EKONOMI KELUARGA DI DESA UMPUNGENG KECAMATAN LALABATA KABUPATEN SOPPENG
}

\author{
Andi Sawe Ri Esso ${ }^{1}$, Sumriah ${ }^{2}$, Nurdiana ${ }^{3}$, Muhammad Hasan ${ }^{4}$ \\ ${ }^{1}$ Manajemen Sekolah Tinggi Ilmu Ekonomi Pembangunan Makassar \\ Email: andisaweriesso@yahoo.co.id \\ ${ }^{2}$ Pendidikan Ekonomi Program Sarjana Fakultas Ekonomi Universitas Negeri Makassar \\ Email: samriahria09@gmail.com \\ ${ }^{3}$ Pendidikan ekonomi Universitas Negeri Makassar \\ Email: nurdiananurdin.unm@gmail.com \\ ${ }^{4}$ Pendidikan Ekonomi Universitas Negeri Makassar \\ Email: m.hasan@unm.ac.id
}

\begin{abstract}
This study aims to determine the effect of the level of women's participation in entrepreneurship on the socio-economic level of the family. Technique of data analysis using simple linear regression analysis, sample determination with purposive random sampling and research data collection tools using a questionnaire. The results of this study indicate that: 1) The level of women's participation in entrepreneurship is positive and significantly affects the socio-economic level of the family; 2) The greater the level of women's participation in entrepreneurship, the higher the socio-economic level of the family.
\end{abstract}

Keywords: Women's participation in entrepreneurship; family socio-economic level

\begin{abstract}
Abstrak. Penelitian ini bertujuan untuk mengetahui pengaruh tingkat partisipasi perempuan dalam berwirausaha terhadap tingkat sosial ekonomi keluarga. Tehnik Analisis data menggunakan analisis regresi linear sederhana, penentuan sampel dengan purposive random sampling dan alat pengumpulan data penelitian menggunakan kuesioner. Hasil penelitian ini menunjukkan bahwa: 1) Tingkat partisipasi perempuan dalam berwirausaha secara positif dan signifikan berpengaruh terhadap tingkat sosial ekonomi keluarga; 2) Semakin besar tingkat partisipasi perempuan dalam berwirausaha maka semakin meningkat pula tingkat sosial ekonomi keluarga.
\end{abstract}

Kata kunci: Partisipasi perempuan dalam berwirausaha; tingkat sosial ekonomi keluarga

\section{PENDAHULUAN}

Dalam sosial ekonomi keluarga sangat di tentukan oleh partisispasi perempuan dalam berwirausaha. Perempuan merupakan makhluk yang diciptakan dengan berbagai kelebihan, sehingga banyak topik yang diangkat dengan latar belakang perempuan. Pembahasan mengenai perempuan dengan sejuta problematika melahirkan pemikiran beberapa ahli yang menghasilkan teori-teori sosial

Tabel 1. Mata pencaharian warga desa Umpungeng Kecamatan Lalabata Kabupaten Soppeng

\begin{tabular}{|c|c|c|c|}
\hline Pekerjaan & Laki-laki & & Perempuan \\
\hline PNS & 20 & & 15 \\
\hline Wirausaha & 153 & & 28 \\
\hline Perdangangan & 10 & & 8 \\
\hline Pegawai Swasta & 23 & 986 & 20 \\
\hline Lain-lainnya & & & 36 \\
\hline
\end{tabular}

mengenai sisi perempuan seperti feminisme (gender) dengan beberapa paradigma (Faqih, 2012: 80-98). Di Desa Umpungeng Kecamatan Lalabata Kabupaten Soppeng ini jumlah penduduknya sebanyak 4.058 jiwa. Berdasarkan observasi yang telah dilakukan di bawah ini daftar mata pencaharian Di Desa Umpungeng Kecamatan Lalabata Kabupaten Soppeng baik laki-laki maupun Perempuan, sebagai berikut : 
Sumber : Kantor Desa Umpungeng Kecamatan Lalabata Kabupaten Soppeng 2015

Di Desa Umpungeng Kecamatan pengaruh antar variabel. Seberapa besar Lalabata Kabupaten Soppeng ini dulu masih sangat sedikit perempuan yang berwirausaha, kebanyakan hanya mengurus rumah tangga serta hanya mengandalkan pendapatan suami. Dalam perkembangannya terjadi perubahan pola pikir sehingga saat ini perempuan di Desa Umpungeng sudah terlibat dalam berbagai kegiatan wirausaha untuk membantu ekonomi keluarganya meskipun masih skala mikro. Berdasar uraian tersebut, menarik untuk diteliti bagaimana "pengaruh tingkat partisipasi perempuan dalam berwirausaha terhadap tingkat sosial ekonomi keluarga di Desa Umpungeng Kecamatan Lalabata Kabupaten Soppeng”.

\section{METODE}

Jenis penelitian ini adalah penelitian explanatory yaitu penelitian yang bertujuan menelaah kausalitas antar variabel yang menjelaskan suatu fenomena tertentu untuk menjelaskan atau membuktikan hubungan atau pengaruh tingkat partisipasi perempuan dalam berwirausaha terhadap tingkat sosial ekonomi keluarga di desa Umpungeng Kecamatan Lalabata Kabupaten Soppeng. Jumlah sampel dalam penelitian ini sebanya 33 perempuan yang berwirausaha untuk membantu tingkat ekonomi keluarganya di desa Umpungeng Kecamatan Lalabata Kabupaten Soppeng.

Adapun teknik pengumpulan data yang digunakan dalam penelitian ini yaitu Kuesioner, Observasi, dan Dokumentasi. Adapun teknik analisis data dilakukan dengan menggunakan uji instrumen yang terdiri dari Uji Instrumen data (Uji validitas, Uji realibilitas), Uji Asumsi Klasik (Uji Normalitas, Uji heteroskadisitas), Uji Analisis Regresi Linear Sederhana, Uji Hipotesis, dan Uji Koefisien Korelasi. Untuk dapat memberikan penafsiran terhadap koefisien korelasi yang di temukan tersebut memiliki nilai besar atau kecil, maka dapat berpedoman pada ketentuan yang telah ditetapkan sebagai berikut :

Tabel 2. Pedoman interpertasi nilai koefisien korelasi

\begin{tabular}{lcl}
\hline No & Interval Koefisien & Tingkat Hubungan \\
\hline 1 & $0,00-0,199$ & Sangat rendah \\
2 & $0,20-0,399$ & Rendah \\
3 & $0,40-0.499$ & Sedang \\
4 & $0,60-0,799$ & Kuat \\
5 & $0,80-0,1000$ & Sangat kuat \\
\hline
\end{tabular}

Sumber: Sunjoyo (2013: 141)

\section{HASIL DAN PEMBAHASAN}

Desa Umpungeng merupakan salah satu Desa yang berada di Kecamatan Lalabata Kabupaten Soppeng dengan jarak +/- $28 \mathrm{KM}$ dari ibu kota Kabupaten Soppeng dan berada pada ketinggian $1000 \mathrm{~m}$ diatas permukaan laut. Jenis tanaman perkebunan yang menjadi pokok pencaharian di Desa Umpungeng adalah jenis tanaman cengkeh, aren, coklat, kopi, pisang dan lain-lain. Selain itu beberapa penduduk juga melakukan usaha pemanfaatan karet pada pohon pinus yang juga sangat banyak di Desa Umpungeng. Jenis Usaha, Partisipasi Perempuan Dalam Berwirausaha dan Tingkat Sosial Ekonomi Keluarga Responden dapat dilihat pada tabel berikut:

Tabel 3. Distribusi responden menurut jenis usaha di Desa Umpungeng Kecamatan Lalabata Kabupaten Soppeng Tahun 2018

\begin{tabular}{lcc}
\hline Jenis Usaha & Jumlah Responden & Persentase (\%) \\
\hline Usaha Eceran & 12 & 36,37 \\
Usaha Alat Listrik & 1 & 3,03 \\
Usaha Jual Online & 4 & 12,12 \\
Usaha Jual Pulsa & 4 & 12,12 \\
Penjahit & 4 & 12,12 \\
Menjual Pakean & 4 & 12,12 \\
Menjual Obat-obatan & 2 & 6,06 \\
Usaha Salon & 1 & 3,03 \\
Pedagang & 1 & 3,03 \\
\hline Jumlah & 33 & 100 \\
\hline
\end{tabular}

Sumber: Olah Data Primer 2018 
Keabsahan Data

1. Uji Validitas

Tabel 4. Uji validitas variabel

\begin{tabular}{|c|c|c|c|c|}
\hline Variabel & Item & r hitung & $\mathrm{r}$ tabel & Keterangan \\
\hline \multirow{16}{*}{$\begin{array}{l}\text { Tingkat Partisipasi } \\
\text { perempuan dalam } \\
\text { berwirausaha } \\
\text { (X) }\end{array}$} & $\mathrm{X} 1$ & ,461 & 0,291 & Valid \\
\hline & $\mathrm{X} 2$ & ,308 & 0,291 & Valid \\
\hline & X3 & , 484 & 0,291 & Valid \\
\hline & $\mathrm{X} 4$ & ,419 & 0,291 & Valid \\
\hline & $X 5$ & , 435 & 0,291 & Valid \\
\hline & X6 & ,576 & 0,291 & Valid \\
\hline & X7 & ,330 & 0,291 & Valid \\
\hline & $\mathrm{X} 8$ & ,437 & 0,291 & Valid \\
\hline & X9 & ,412 & 0,291 & Valid \\
\hline & $\mathrm{X} 10$ & ,573 & 0,291 & Valid \\
\hline & $\mathrm{X} 11$ & 331 & 0,291 & Valid \\
\hline & $\mathrm{X} 12$ & ,401 & 0,291 & Valid \\
\hline & $\mathrm{X} 13$ & ,462 & 0,291 & Valid \\
\hline & X14 & ,385 & 0,291 & Valid \\
\hline & $\mathrm{X} 15$ & ,495 & 0,291 & Valid \\
\hline & $\mathrm{X} 16$ & ,464 & 0,291 & Valid \\
\hline \multirow{15}{*}{$\begin{array}{l}\text { Tingkat Sosial Ekonomi } \\
\text { Keluarga (Y) }\end{array}$} & Y1 & 315 & 0,291 & Valid \\
\hline & $\mathrm{Y} 2$ & ,510 & 0,291 & Valid \\
\hline & Y3 & ,404 & 0,291 & Valid \\
\hline & Y4 & , 454 & 0,291 & Valid \\
\hline & Y5 & ,519 & 0,291 & Valid \\
\hline & Y6 & ,444 & 0,291 & Valid \\
\hline & Y7 & 401 & 0,291 & Valid \\
\hline & Y8 & 461 & 0,291 & Valid \\
\hline & Y9 & ,563 & 0,291 & Valid \\
\hline & Y10 & ,394 & 0,291 & Valid \\
\hline & Y11 & ,375 & 0,291 & Valid \\
\hline & Y12 & 305 & 0,291 & Valid \\
\hline & Y13 & ,333 & 0,291 & Valid \\
\hline & Y14 & ,499 & 0,291 & Valid \\
\hline & Y15 & ,339 & 0,291 & Valid \\
\hline
\end{tabular}

2. Uji Reliabilitas

Teknik yang digunakan untuk dikatakan baik jika memiliki Cronbach's Alpha mengukur tingkat reliabilitas adalah $>0,60$. Tabel di bawah ini menunjukkan hasil Cronbach's Alpha dengan cara pengujian realibilitas dengan menggunakan membangdingkan nilai alpha dengan SPSS 21.

Tabel 5. Uji realibitas variabel

\begin{tabular}{llll}
\hline Varibel & Cronbach's Alpha & N of Item & Keterangan \\
\hline $\begin{array}{l}\text { Tingkat Partisipasi Perempuan Dalam } \\
\begin{array}{l}\text { Berwirausaha } \\
\text { Tingkat Sosial Ekonomi Keluarga }\end{array}\end{array}$ &, 841 & 16 & Reliabel \\
\hline
\end{tabular}

Sumber : Hasil Output SPSS 21

Dari tabel 5 menunjukkan bahwa variabel tingkat partisipasi perempuan dalam berwirausaha dapat dikatakan reliabel. Pada variabel tingkat sosial ekonomi keluarga, nilai Cronbach's Alpha yang diperoleh sebesar 0,846 . Hal ini dapat disimpulkan bahwa semua indikator atau pernyataan pada variabel tingkat partisipasi perempuan dan tingkat sosial ekonomi keluarga dinyatakan handal atau dapat dipercaya sebagai alat ukur.

\section{Uji Asumsi Klasik}

Untuk menyakinkan bahwa persamaan garis regresi yang diperoleh adalah linear dan dapat dipergunakan (valid) untuk mencari 
peramalan, maka akan dijadikan pengujian asumsi normalitas dan heteroskedastisitas.

1. Uji Normalitas

Uji normalitas data yang digunakan untuk mengetahui apakah populasi data berdistribusi normal atau tidak. Model regresi

Tabel 6. Uji Normalitas

\begin{tabular}{llr}
\hline & & \multicolumn{2}{c}{$\begin{array}{c}\text { Unstandardized } \\
\text { Residual }\end{array}$} \\
\hline $\mathrm{N}$ & & 33 \\
Normal Parameters & Mean & 0,0000000 \\
& Std. Deviation & 1,57977707 \\
Most Extreme Differences & Absolute & 0,159 \\
& Positive & 0,159 \\
Kolmogorov-Smirnov Z & Negative & 0,140 \\
Asymp. Sig. & & 0,912 \\
& & 0,377
\end{tabular}

Sumber: Hasil Output SPSS 21

Berdasarkan hasil output tabel 6, dketahui bahwa nilai signifikansi yaitu 0,377

besar dari 0,005 sehingga dapat dikatakan bahwa data memiliki distrribusi yang normal. yang baik adalah distribusi data normal atau mendekat normal. Deteksi normal dilakukan dengan penyebaran data (titik) pada sumbu diagonal dari grafik. Berikut ini hasil pengujian normalitas melalui SPSS 21. yang berarti bahwa nilain Asymp. Sig lebih

2. Uji Heteroskadisitas

Berikut ini hasil pengujian heterokedastisitas melalui SPSS 21 :

Tabel 7. Uji Heterokedastisitas

\begin{tabular}{lll}
\hline No. & Variabel & Sig. \\
\hline 1. & Tingkat Partisipasi Perempuan & 0,001 \\
& Dalam Berwirausaha & \\
\hline
\end{tabular}

\section{Sumber: Hasil Output SPSS 21}

Berdasarkan hasil output tabel 7, diketahui bahwa nilai signifikan pada variabel tingkat partisipasi perempuan dalam berwirausaha yaitu 0,001 yang berarti lebih kecil dari 0,05. Sehingga dapat dikatakan

bahwa tidak terjadi heterokedastisitas pada variabel tingkat partisipasi perempuan dalam berwirausaha.

Sementara itu, untuk grafik scatterplot dapat dilihat pada gambar di bawah ini :

Gambar 3. Grafik Scatterplot

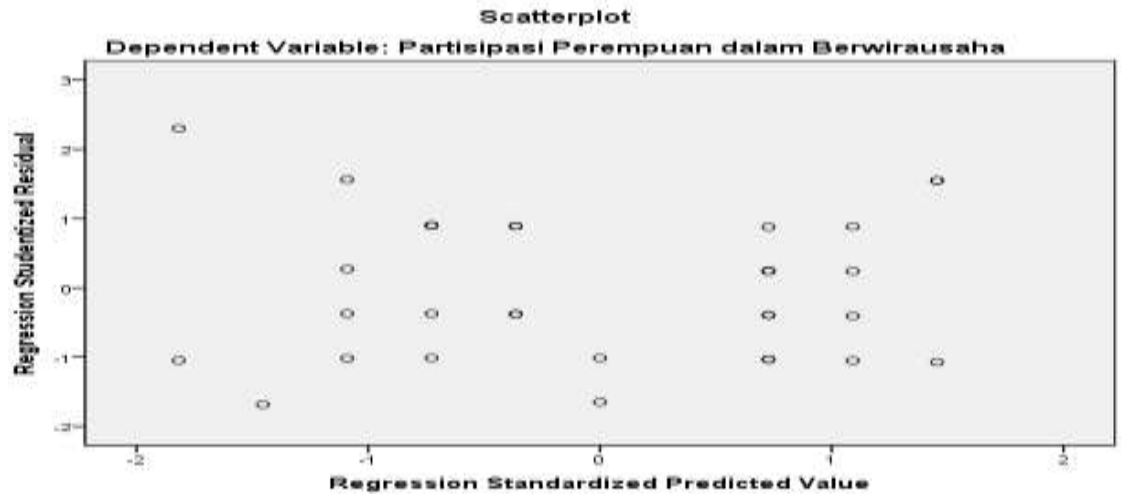

Berdasarkan gambar 1 diketahui bahwa tidak ada pola yang jelas serta titik-titik meyebar di atas dan di bawah angka 0 pada sumbu Y maka tidak terjadi heterokedastisitas sehingga model regresi dan ideal dapat terpenuhi.

\section{Pengujian hipotesis}

1. Analisis Regresi Linear Sederhana

Analisis statistik yang digunakan dalam penelitian ini yaitu regresi linear sederhana untuk mengetahui besarnya pengaruh variabel bebas (independent variabel) yaitu tingkat partisipasi perempuan dalam berwirausaha (X) terhadap variabel terikat (dependernt variabel) yaitu tingkat sosial ekonomi keluarga (Y). 
Besarnya pengaruh variabel tersebut dapat dilihat pada tabel berikut:

Tabel 8. Hasil Uji Regresi Linear Sederhana

\begin{tabular}{llll}
\hline No. & Model & B & Sig. \\
\hline 1 & Constant & 53,986 & 0,000 \\
\hline & $\begin{array}{l}\text { Tingkat Partisipasi Perempuan Dalam } \\
\text { Berwirausaha }\end{array}$ & 1,018 & 0,001
\end{tabular}

Sumber: Hasil Output SPSS 21.

Hasil penghitungan koefisien regresi sederhana memperlihatkan nilai koefisien konstanta adalah 53,986 koefisien variabel (X) adalah 1,018 sehingga diperoleh persamaan regresi $\mathrm{Y}=53,986+1,018 \mathrm{X}$

Nilai koefisien variabel $(\mathrm{X})$ positif $(1,018)$ yang terdapat pada koefisien regresi variabel bebas menggambarkan bahwa arah hubungan antara variabel bebas (tingkat partisipasi perempuan dalam berwirausaha) dengan variabel terikat (tingkat sosial ekonomi satu satuan variabel tingkat partisipasi perempuan dalam berwirausaha maka akan menyebabkan kenaikan tingkat sosial ekonomi keluarga 1,018.

\section{Ujit}

Uji-t dilakukan untuk menguji apakah hipotesis signifikan yang ditawarkan dapat diterima atau tidak. Kriteria pengujian taraf signifikan $\alpha=0,05$. Berikut hasil perhitungan dengan SPSS 21 for windows

keluarga) adalah searah, dimana setiap kenaikan

Tabel 9. Hasil Uji t

\begin{tabular}{llll}
\hline No. & Variabel & T & Sig. \\
\hline 1. & Tingkat Partisipasi Perempuan Dalam & 0,180 & 0,001 \\
& Berwirausaha
\end{tabular}

Sumber : Hasil Output SPSS 21

Dari hasil tabel 9 dapat dilihat bahwa ada pengaruh yang signifikan antara variabel tingkat partisipasi perempuan dalam berwirausaha (X) terhadap variabel tingkat sosial ekonomi keluarga (Y) dengan probabilitas sig. sebesar 0,001 dimana nilai ini jauh di bawah 0,05. Hal ini berarti bahwa tingkat partisipasi perempuan dalam berwirausaha mempunyai pengaruh yang signifikan terhadap tingkat sosial ekonomi

Tabel 10. Hasil Analisis Koefisien Korelasi

\begin{tabular}{lllll}
\hline Model & $\mathrm{R}$ & $\mathrm{R}$ Square & Adjusted R Square & Std. Error \\
\hline 1. & $0,814^{\mathrm{a}}$ & 0,810 & 0,832 & 1,60506 \\
\hline
\end{tabular}

Sumber : Hasil Output SPSS 21

Dari tabel 10, hasil $R$ Square yang diperoleh sebesar 0,810, yang berarti kemampuan vaariabel tingkat partisipasi perempuan dalam berwirausaha dalam meningkatkan tingkat sosial ekonomi keluarga adalah sebesar $81 \%$ sementara sisanya $19 \%$ dijelaskan oleh variabel lainnya yang tidak diteliti dalam penelitian ini.

Implikasi hasil penelitian yang telah dianalisis dapat diuraikan sebagai berikut:

\section{Tingkat partisipasi perempuan dalam berwirausaha}

Berdasarkan hasil analisis yang telah diuraikan diperoleh hasil bahwa tingkat

keluarga di Desa Umpungeng Kecamatan Lalabata Kabupaten Soppeng.

\section{Uji Koefisien Korelasi}

Analisis koefisien korelasi digunakan untuk dapat memberikan penafsiran terhadap koefisien korelasi yang ditemukan tersebut memiliki nilai besar atau kecil. Berikut ini analisis koefisien korelasi dengan menggunakan SPSS 21 for windows.

partisipasi perempuan dalam berwirausaha berpengaruh positif terhadap tingkat sosial ekonomi keluarga di Desa Umpungeng Kecamatan Lalabata Kabupaten Soppeng.

Adanya kondisi ekonomi suami yang rendah mendorong isteri atau perempuan untuk berpartisipasi mencari penghasilan dengan merubah perannya dari sektor domestik atau dalam rumah tangga ke sektor publik atau diluar rumah tangga (Munandar, 2002:47).

Dari hasil penelitian ini dapat dipahami bahwa tingkat partisipasi perempuan dalam berwirausaha berupa keterlibatan mental dan emosi, adanya motivasi dan adanya tanggung jawab adalah salah satu bagian penting dalam meningkatkan tingkat sosial ekonomi keluarga 
di Desa Umpungeng Kecamatan Lalabata Kabupaten Soppeng.

\section{Pengaruh tingkat partisipasi perempuan terhadap tingkat sosial ekonomi keluarga di Desa Umpungeng Kecamatan Lalabata Kabupaten Soppeng}

Berdasarkan hasil analisis yang telah dipaparkan diatas diperoleh hasil bahwa variabel tingkat partisipasi perempuan dalam berwirausaha $(\mathrm{X})$ berpengaruh signifikan terhadap tingkat sosial ekonomi keluarga (Y) di Desa Umpungeng Kecamatan Lalabata Kabupaten Soppeng.

Berdasarkan hasil uji hipotesis dari uji $\mathrm{R}$ pada tabel 10 menunjukkan bahwa semua variabel independen yaitu tingkat partisipasi perempuan dalam berwirausaha memengaruhi tingkat sosial ekonomi keluarga (Y) secara positif dan signifikan. Hal ini bisa dilihat dari nilai $\mathrm{R}$ bisa diartikan bahwa kemampuan variabel tingkat partisipasi perempuan dalam berwirausaha dalam meningkatkan tingkat sosial ekonomi keluarga. Koefisien bersifat positif artinya terjadi hubungan positif antara variabel tingkat partisipasi perempuan dalam berwirausaha $(\mathrm{X})$ dan variabel tingkat sosial ekonomi keluarga (Y), semakin besar partisipasi perempuan dalam berwirausaha maka semakin tinggi pula tingkat sosial ekonomi keluarga. Dengan demikian dapat ditarik sebuah kesimpulan bahwa tingkat partisipasi perempuan dalam berwirausaha memengaruhi tingkat sosial ekonomi keluarga, dimana dengan adanya partisipasi perempuan dalam berwirausaha di Desa Umpungeng Kecamatan Lalabata Kabupaten Soppeng membuktikan bahwa akan meningkatkan tingkat sosial ekonomi keluarga.

Hasil pengujian menunjukkan bahwa hasil penelitian ini sesuai dengan penelitian Indah Aswiyanti (2016) juga menemukan bahwa dalam menunjang atau meningkatkan perekonomian keluarga, peran perempuan dalam menjalankan usaha sangat mendukung .

Pada dasarnya manusia memang harus bekerja, untuk memenuhi kebutuhan hidupnya. Menurut Aswiyanti (2016) Perempuan di pedesaan bekerja bukan semata-mata untuk mengisi waktu luang atau memgembangkan karir, tetapi untuk mencari nafkah karena pendapatan suaminya dikatakan kurang mencukupi kebutuhan sehingga banyak perempuan atau ibu rumah tangga yang bekerja.
Apabila pendapatan suami kurang untuk memenuhi kebutuhan sehari-hari, maka tidak dapat dipungkiri adanya peran yang harus dilakukan oleh perempuan selain pekerjaan domestik.

\section{SIMPULAN DAN SARAN Simpulan}

Berdasarkan hasil analisis dan pembahasan, maka kesimpulan dari penelitian ini sebagai berikut :

1. Tingkat partisipasi perempuan dalam berwirausaha berpengaruh secara positif dan signifikan terhadap tingkat sosial ekonomi keluarga di Desa Umpungeng Kecamatan Lalabata Kabuapaten Soppeng. Artinya pengaruh tingkat partisipasi perempuan dalam berwirausaha terhadap tingkat sosial ekonomi keluarga disebabkan karena besarnya pengaruh partisipasi perempuan dalam meningkatkan sosial ekonomi keluarga.

2. Tingkat Sosial ekonomi keluarga sebagai suatu keadaan atau kedudukan yang diatur secara sosial dan menetapkan seseorang dalam posisi tertentu dalam struktur masyarakat. Pemberian posisi ini disertai pula seperangkat hak dan kewajiban yang harus dipenuhi sipembawa status misalnya pendapatan dan pekerjaan.

3. Berdasarkan hasil uji hipotesis dan uji t menunjukkan bahwa variabel independen yaitu tingkat partisipasi perempuan memengaruhi tingkat sosial ekonomi keluarga secara positif dan signifikan. Jadi semakin besar tingkat partisipasi perempuan dalam berwirausaha (X) maka semakin meningkat pula tingkat sosial ekonomi keluarga di Desa Umpungeng Kecamatan Lalabata Kabapaten Soppeng.

\section{Saran}

Partisipasi Perempuan dalam menjalankan usaha salah satunya adalah masalah ekonomi yaitu membantu suami untuk meningkatkan sosial ekonomi keluarga. diharapkan dengan hal tersebut, sebagian besar kebutuhan dalam keluarga dapat terpenuhi. Selain itu perempuan juga harus terus mengembangkan kemauannya dalam berwirausaha dengan menambah pengetahuan dan wawasan dengan mengikuti berbagai pelatihan agar skillnya dapat meningkat. 


\section{DAFTAR RUJUKAN}

Arikunto, S. 2010. Prosedur Penelitian Suatu Pendekatan Praktik. Jakarta: Rineka Cipta.

Artini, Ni Wayan Putu dan Handayani, 2009. Kontribusi Pendapatan Ibu Rumah Tangga Pembuat Makanan Olahan Terhadap Pendapatan Keluarga. Piramida, 5. :1;9-15

Asra, A, \& Sutomo, S. 2014. Pengantar Statistika II:Cetakan Pertama, Penerbit PT RajaGrafindo Persada.Jakarta

Aswiyati, I. (2016). "Peran Wanita dalam Menunjang Perekonomian Rumah Tangga Petani Tradisional untuk Penanggulangan Kemiskinan di Desa Kuwil Kecamatan Kalawat”. Jurnal Holistik (Nomor 17 Tahun 9).

Boruologo, Ihsana Sabriani, 2007. Pemberdayaan Kaum Ibu Sebagai Upaya Memutus Mata Rantai Kemiskinan, Volume. XXIII. No. 2. April, Juni. 2007.

Dahniar,1998. Kemandirian: Pandanagn Seorang Manager Perempuan. Perempuan Indonesia, Kelompok Studi Wanita Pusat Penelitian Universitas Brawijaya Malang 1998.

Dewi, Putu Martini. 2012. Partisipasi Tenaga Kerja Perempuan dalam Meningkatkan Pendapatan Keluarga. (Jurnal Ekonomi Kuantitatif Terapan) Volume. 5. No. 2. Januari. 2012.

Fakih. Mansour, Analisis Gender \& Transformasi Sosial, Pustaka Pelajar, Yogyakarta, 2012.

Handayani, C. S. \& Novianto, A. (2011). Kuasa Wanita Jawa. Yogyakarta: LkiS.

Marwanti, Sri. 2012. Model Pemberdayaan Perempuan Miskin Melalui Pengembangan Kewirausahaan Keluarga Menuju Ekonomi Kreatif Di
Kabupaten Karanganyar. Volume. 9. No. 1. September. 2012.

Mokalu, J.Benedicta. 2016. Perempuan Berwirausaha Usaha Mengentas Ekonomi Keluarga. (jurnal LPPM Bidang EkoSosBudKum) Volume. 3. No. 2. Oktober. 2016.

Munandar, Utami. 2002. Mengembangkan Bakat dan Kreativitas Anak Sekolah. Jakarta : PT. Gramedia.

Munfaqirah, Sitti. 2016. Faktor Yang Mempengaruhi Wirausaha Wanita Miskin Untuk Mencapai Keberhasilan Usaha. (Jurnal JIBEKA) Volume. 10. No. 1. Agustus. 2016.

Nugroho, R. (2011). Gender dan StrategiPengarus-utamanya di Indonesia. Yogyakarta: Pustaka Pelajar.

Rizkia, Nur Frida. 2017. Peran perempuan dalam meningkatkan perekonomian keluarga melalui Program P2WKSS di Sumber Gamol, Balecatur, Gamping, Sleman.

Saparinah Sadli, 1998. Kemandirian

Perempuan Tinjauan Psikologis.

Kelompok Studi Wanita Pusat Penelitian Universitas Brawijaya Malang 1998.

Sayogyo, Pudjiwati, 1996. Peran Wanita Dalam Rumah Tangga dan Masyarakat di Pedesaan Jawa, Gramedia. 